\title{
Human approach in the quality management system of manufacturing SMEs in Mexico Theoretical review and proposal of a conceptual model
}

Virginia Mendoza

Hernández.

Universidad Autónoma del

Estado de Puebla

vmenher@yahoo.com.mx

Beatriz Pico González Universidad Autónoma del

Estado de Puebla

beatriz.pico@upaep.mx

\section{Eleuterio Cornelio}

Aquiahuatl

Universidad Autónoma del

Estado de Puebla

elcoraquito@gmail.com

\begin{abstract}
Currently, globalization and competitiveness exert an enormous pressure on small and medium enterprises (SMEs) in the manufacturing sector in Mexico, for that reason they must be more effective and flexible to meet customer demand. In this article, we reviewed the literature on the subject according to the level of significance of variables like human factor, quality culture, quality management system (QMS) and innovation, considered as key elements of a latent competitive scale as from their exploration and explanation. The main objective of this research is to carry out a critical analysis by relating the importance of the human factor of QMS, through research on socio-emotional, intellectual factors and ethics values for achieving the effectiveness of QMS at all organization levels; it also provides a link between variables of quality culture, value propositions, and innovation. Finally, this work discusses the design of a human factor-based quality model to ensure the value propositions for customer and stakeholders' satisfaction.
\end{abstract}

Keywords: human factor, quality culture, quality management system, total quality management, innovation. 


\section{Enfoque humano en el sistema de gestión de la calidad de la Pyme de manu- factura en México. Revisión teórica y propuesta de un modelo conceptual}

\section{Resumen}

Actualmente se observa cómo la globalización y la competitividad ejercen una fuerte presión a las pequeñas y medianas empresas (Pyme) del sector de manufactura en México; por ello, deben ser efectivas y flexibles para atender la demanda de sus clientes. En este artículo, se revisó la literatura en función de su nivel de significancia de las variables tales como factor humano, cultura de calidad, sistema de gestión de la calidad (SGC) e innovación, considerados como elementos claves de una escala de competitividad latente que proporciona su exploración y explicación. El principal objetivo de esta investigación es realizar un análisis crítico al relacionar la importancia del factor humano en el sistema de gestión de calidad en aspectos tales como factores socioemocionales e intelectuales y valores éticos para la mejora de los resultados en todos los niveles de la organización. Finalmente, se reflexionó sobre el diseño de un modelo sustentado en el factor humano para garantizar las propuestas de valor a los clientes y partes interesadas a través de la relación de variables de cultura de calidad, SGC e innovación.

Palabras clave: factor humano, cultura de calidad, sistema de gestión de calidad, gestión de calidad total, propuesta de valor, innovación.

\section{Introduction}

Customer requirements for quality products and services have been increased; Castro (2007) notes that out of 5000 certified companies only $20 \%$ are manufacturing SMEs in Mexico, and that there is still a lack of knowledge about benefits from the effectiveness of QMS. In addition, 80\% of manufacturing SMEs in Mexico fail in the first five years and $90 \%$ in less than ten years; for that reason, those SMEs that want to survive must rapidly adjust to such demands where QMS has become a business strategy, especially when it is required to get new markets.

It is noteworthy that some authors from european countries like England, Turkey, Spain, Greece and Australia, have mentioned the lack of sustenance of quality culture and of innovation in the manufacturing SMEs, that can include transcendental human factors at the different levels of the organization, and that can be evaluated with tangible or intangible indicators (Wilford, 2007; Elçi, Kitapçi and Ertürk 2007; Fotopoulos, Psomas and Vouzas 2010; Camisón and Pérez, 2010; Castro, 
González, Guenaga and Mijangos 2009; Stewart and Waddell, 2008). On the other hand, in Asian countries like China, Malaysia, Thailand, and Vietnam, in relation to the activities of manufacturing SMEs, few studies have determined the correlation of value propositions in relation to customer satisfaction and the inclusion of a quality culture that is implicit in QMS (Tang, Aoieong and Tsui, 2010; Ismail, Madi Bin and Francis 2009; Hoang, Igel and Laosirihongthong, 2010).

In that sense, the argument is that manufacturing SMEs in Mexico have not considered socio-emotional and intellectual factors and ethics values within a quality culture, that is part of an integrative model of QMS to improve the aptitude and attitude of people who represent the most important value faced to any other asset in the business, and can carry an innovation process and value-added products and service to get customer and stakeholder ${ }^{1}$ satisfaction. However, nowadays, these factors have not been fully considered in accreditation, certification and quality awards, with a focus on just the requirements and corporate image improvement. These aspects justify the following question:

What results have been found by the authors of the research articles, that involve the human factor for the effectiveness of QMS in manufacturing SMEs in relation to socio-emotional and intellectual skills, and ethical values as value propositions to satisfy their customers.

\section{Theoretical framework}

In the early 70's the manufacturing $\mathrm{SMEs}^{2}$ had a clearly secondary role in global economy, as a result of a strong mass production trend that eliminated any possibility of being properly investigated, that is, manufacturing SMEs are considered a reply to large organizations. From that decade a series of changes have taken place that raise the need for greater flexibility in production lines to meet the most demanding customers, with a higher rate of production diversification at low costs (Braidot, Formento and Nicoloini, 2003). SMEs are considered a strong weight in

\footnotetext{
${ }^{1}$ The organization must consistently meet quality requirements of stakeholders and customers according to ISO 9000:2005.

${ }^{2}$ Small and medium enterprises worldwide represent the segment of the economy that contributes the largest number of economic units and personnel employed, provided these are the following sector: micro industry, up to 15 people, the value of its net sales of 30 million pesos annual; small industry, up to 100 people and its net sales do not exceed the amount of $400 \mathrm{mil}$; medium industry, up to 250 people and the value of sales would not exceed the amount of 1100 million pesos per year.
} 
relation with the total number of companies or their contribution to gross domestic product (GDP) and Mexico's contribution appears to be a lower one in a global environment (see table 1) so, Romero (2006) mentioned that in most Organization for Economic Cooperation and Development (OECD)' $\mathrm{s}^{3}$ countries, manufacturing SMEs represent between $96 \%$ and $99 \%$ of the total number of businesses and contribute with about one sixth of industrial production and between $60 \%$ and $70 \%$ of employment (OECD, 2009).

Table 1

Contribution of GDP in the World Manufacturing SME

\begin{tabular}{l|l|l|l}
\hline \multicolumn{1}{c|}{$\mathbf{7 0 \%}$} & \multicolumn{1}{|c|}{$\mathbf{5 0 \%}$} & Between $\mathbf{7 0 \%}$ and 80\% & In Latin America \\
\hline $\begin{array}{l}\text { Developed countries of } \\
\text { Europe and Japan }\end{array}$ & $\begin{array}{l}\text { Developing countries } \\
\text { of Europe }\end{array}$ & African Countries & Brazil 60\% \\
& & $\begin{array}{l}\text { Chile 60\% } \\
\text { México 48\% }\end{array}$ \\
\hline
\end{tabular}

Source: Own, Adapted from OECD (2009)

That is why manufacturing SMEs are not only important but also necessary for the economic development of any country, since they contribute to employment creation, therefore, it is important to emphasize that if they do not create strategic plans to strengthen themselves, the global crisis will continue to affect their activities (Macias, s/f). In an analysis of the Latin America environment, Mexico was the most affected country by the 2009 crisis placed at the sixth position (Economic Commission for Latin America [ECLA], 2010) ${ }^{4}$ and in place 58 of global competitiveness (World Economic Forum [WEF], 2011-2012).

\footnotetext{
${ }^{3}$ The Organization for Economic Cooperation and Development, founded in 1961, groups 31 member countries and their purpose is: to support sustainable economic development, increase employment, raise living standards, maintain financial stability, support economic development in other countries and contribute to world trade growth.

${ }^{4}$ The Economic Commission for Latin America contributes to economic development in Latin America and in a similar way coordinate their actions to promote and strengthen economic relations among the countries themselves and with other nations.

${ }^{5}$ The World Economic Forum is an impartial and independent non-governmental and non-profit organization dedicated to improving the state of the world through the incursion of leading global companies, regional and industry.
} 
Because of this, the world class manufacturing SMEs in Mexico must implement QSM capable of creating high added-value products with sustained profits over time through the application of innovative strategies, commitment to quality and customer's satisfaction. All of the manufacturing SMEs seeking excellence in their business model should make changes in their management process, which this research focuses on three pillars as mentioned below:

- Quality culture: According to the review of literature on the subject, Kotk (2004) and Elçi et al. (2007) conceptualized this variable like comparative model assumptions to solve problems of external adaptation and internal integration and show to their news members the correct way of perceiving, thinking and feeling. Moreover, Mobley, Wang and Fang (2005) (cited by Kuo and Kou, 2010) determined this variable, like a set of values, beliefs, understanding and thinking and behavioral norms that are shared by all members of society.

- QMS: Danvila and Sastre (2007) based their research on an interesting definition of total quality management (TQM) that is conceived as QMS, therefore both share the purpose of total customer satisfaction through continuous improvement in all the organization process and procedures. Otherwise, Nava and Ríos (2008) mentioned that a QMS can be considered as a multi-system, like certification, quality awards, customer audit, and TQM and Perdomo and González (2004) mentioned that a QMS can be represented like ISO, Kaizen, 6 Sigma, 5 `s, etc. On their part, Sila and Ebrahimpour (2003) investigated different approaches to TQM and conclude that there is not only one definition for QMS. In general terms, their focus is about continuous improvement, customer focus, human resource management and process management. According to the above, this research included stateof-the-art QMS elements such as ISO 9001:2000, Quality Award, quality cost, success factors and TQM.

- Innovation: The opening of a new quality culture in QMS creates mechanisms for generating ideas and new elements for innovation management within the process and for solving problems in manufacturing SMEs.

The contemporary literature has derived from quality management principles and philosophies of quality gurus such as Feigenbaum, Crosby, Deming and Juran. 
These authors have been instrumental in the evolution of total quality principles. Crosby (1979) pointed a 14-step program to improve quality through defect prevention, Deming (1986) offered 14 points covering the organizational requirements for effective quality, Feigenbaum (1991) supported the integration statistical methodology in processes with the name of total quality control and Juran (1989) provided a framework for total quality, which includes three stages, quality planning, quality improvement and quality control; the total participation of employees is essential to cultural change. This new paradigm and the change in aptitudes and attitudes across the new culture lead to continuous improvement, to achieve the innovation potential needed by more educated and demanding customers (González and Michelena 2000).

\section{Quality culture}

The future of quality depends of the ability to innovate and regenerate, through empowerment and cultural change in the pursuit of excellence (Camisón and Pérez, 2010). Likewise, Belmares and Domínguez (2006) argue that if a customer is not satisfied then the company is not speaking about quality and naming themselves a quality company is invalid, this requires an excellence culture, emotional intelligence (EI), mission, vision, values, process approach and desire to do the right things. Similarly, Palomo (2005) says that SMEs are intended to satisfy a domestic market where volume, price and quality are the most important variables, and that it is important to integrate the culture and QMS to ensure customer and stakeholder satisfaction. In another study, whose purpose was to explore the relationship among quality, response time, security, empathy, perceived value and customer satisfaction of manufacturing SMEs in Malaysia, they got the following results: first, the interaction between the perceived value and response time were not significantly correlated with customer satisfaction. Second, the interaction between perceived value and assurance did not significantly correlate with customer satisfaction and, finally, interaction between perceived value and empathy were significantly correlated with customer satisfaction (Ismail et al., 2008).

Larshon and Shina (1995) and Shlesinger and Heskett (1991) (cited by Gutiérrez and Rubio, 2009) mentioned that there is empirical evidence in which customer satisfaction is the result of employee satisfaction and should incorporate the human factor as a main element in QMS. For manufacturing SME's, the need of human capital strategy is considered essential, such as the knowledge and socio-emotional skills, the absence of these strategies in QMS will not allow manufacturing SMEs 
to be more competitive and innovative (Handžić, 2004 cited by Shackelford and Sun, 2009).

Additionally, Elçi, Kitapçi and Ertürk, (2007) conducted their research to obtain the level of significance among factors such as quality culture, organizational commitment, ethics values, job performance, job satisfaction and sales volume trough a factor analysis and correlation. They interviewed 253 workers of industrial regions of Turkey, the result obtained was a significant relationship between quality culture and performance job, as well as satisfaction customer and sales volume through the commitment of the organization. There was not significant relationship among ethical values, satisfaction and performance; therefore, culture was exposed as the main source of performance. In the same way, Tang et al. (2010) developed a tool to evaluate the quality culture through a questionnaire which measures companies through a scoring system with the conclusion that culture is fundamental in an organization. Therefore, Kull and Narasimhan (2010) mentioned that quality failures are attributed to an organizational culture known as soft management and recognize the importance of values. This study proposed a multilevel model based on sociotechnical systems and quality management theories.

Meanwhile, Sunindijo, Hadikusumo and Ogunl (2007) in Thailand based their research on interviewing managers, engineers and representatives of the manufacturing SMEs. The results showed that EI correlated with manager leadership, using communication and proactive leadership, they also found that EI was correlated with delegation and dynamic behavior, therefore the organization benefited from these results, this raises the question whether the company value is the human factor, and not infrastructure or procedures or money, it means that quality culture is going to be viable at organizations to develop quality human talent (Calderón, Milena and Naranjo, 2006). In turn, Stewart and Waddell (2008) attempted to examine the link between knowledge management and quality culture through a national survey of 1000 certified organizations in Australia; the authors concluded that in order to survive in a competitive environment, organizations must include knowledge management as a fundamental component of quality culture.

Nevertheless, Maguad and Krone (2009) mentioned that the company must have clear and concise policies to define their business ethics and senior management should participate in ethical policies which must reflect strong values, principles and behavior through their actions and decisions across the organization for cus- 
tomer satisfaction and continuous improvement. Organizational climate should be impartial, open and trustworthy to support an ethical culture, which contributes to a lower turnover and increased employee satisfaction.

\section{Quality management systems focused on human factor}

Schenkel (2004) mentioned that ISO 9001:2000 is going to be of a competitive advantage to a basic need, or even a disadvantage in case of lack of it; therefore, ISO 9001:2000 became a documentary requirement to access certain markets, however, when companies implement it, they can forget the potential benefits that the standard provides. He conducted his study on the importance of ISO 9001:2000 and the results related to organizational change, his goal was focused on people communication, ISO 9001:2000 effectiveness clearly dependent on understanding and organizational change through an aptitude and attitude of excellence. Besides, Rahman (2008) compared the practices of QMS between logistics and manufacturing companies through the chi square test of Pearson. The most important variables for logistics were: the delivery time and management commitment and the obstacles were: not implementing quality tools, culture, education, and for manufacturing, the most critical variable was quality circles and the main obstacles were: culture and employee commitment.

Hoang et al. (2010) determined the difference in the service and manufacturing companies QMS by type, size and innovation. The technique used was MANOVA and a structural equation modeling, the result was a major importance between customer satisfaction and management commitment while system analysis, education and management processes are found only average. However, culture and strategic planning were more significant in large firms than in manufacturing SMEs.

With this purpose, Tarí, Llopis, Sempere and Ubeda (2005) through state of the art on the human factor and according to the QMS certificate, found that the education policy variable changed as a mandatory requirement of ISO 9001:2000, and while the selection and recruitment variable was changed in some companies, the career plan variable is rarely changed. Following this, Fotopoulos et al. (2010) examined the interrelationships of TQM and ISO 9001:2000 in Greek organizations certificates; they used a confirmatory factor analysis and structural equation models. The study showed that the management of quality processes, employee involvement and customer focus are the most important, and in a second place, the tools and te- 
chniques to improve quality, the human factor being the key one for TQM growth in the manufacturing SMEs.

Another similar aspect, was noted by Hurtado, Rodríguez, Fuentes and Gallardo (2009) from the state of the art, they identified that ISO 9001:2000 has been a consequence of globalization, this means that manufacturing SMEs adopt the standard to improve market position, they said that it does not guarantee a quality product and a quality service and it only ensures that a company will carry out the implementation of documented procedures for better control, but other studies conducted by Quazi, Chang and Chan (2002) analyzed in Singapore the impact of QMS in the certified companies in ISO 9000, where they grew significantly and with the participation of government, who supported financial costs for standard implementation. On the other hand, Danvila and Sastre (2007) initiated a study to divide the companies into two groups: those with quality certificate and those without it, and noted that companies with a quality certificate offer more training for the efficiency of QMS.

Moreover, a study by Gotzamanin (2010) investigated the advantages and disadvantages of ISO 9001:2000 in Greek SMEs, indicating that continuous improvement and customer satisfaction are the most valued. However, Zeng, Tian and Tam (2007) concluded that although the ISO 9001 standard has been adopted by many companies in China, the main barrier is the attitude that negatively contributes to expected results from certification.

On the other hand, Rositas (2009) said that TQM required to lead manufacturing SMEs towards innovation processes and technological capabilities to evaluate the degree of relationship to TQM with the support of the twelve critical success factors (CSF), The measurement instrument was a 129 point questionnaire, the sample was composed of 50 manufacturing SMEs, and all relationships were positive and statistically significant. In addition, Delgado, Jingtao and Aspinwall (2005) focused their work on comparing the results of TQM and CSF in the United Kingdom manufacturing and construction, with the purpose of identifying similarities and differences. The two industries agree that teamwork and empowerment are the most important factors to achieve a culture such as continuous improvement and training.

Likewise, Parra, Villa and Restrepo (2009) evaluated the European Foundation for Quality Management (EFQM) model through Pearson coefficient, and the result 
showed that manager actions are the profitability, and also exist positive correlations with criteria; persons, partnerships, resources, processes and low correlations with the leadership, policies and strategies. There wasn't a correlation between the results of worker and customer satisfactions, so they recommended that business survival can be achieved if, in addition to economic performance, continuous efforts are made to satisfy their stakeholders. At the same time, Castro et al. (2009) investigated some theoretical evaluations of the leadership role in the EFQM model success in Spain, where the correlations of the leadership sub-criteria with the rest of the model showed to be very significant not only with result but also with the rest of the enablers. However, Wilford (2007) showed throughout the state of the art that an award by itself is not probably the key to achieving excellence, but is an indicator to generate results and this depends on the interpretation, perception, policies and implementation criteria that manages the human factor.

On the other hand, authors like Heras, Casadesus and Marimon (2009) conducted an analysis of ISO 9001:2000 and EFQM model which describes the use of quality improvement tools that impact on the competitiveness of companies and are good for analyzing and generating proposals for improvement. For this purpose, Freitas (2009) mentioned that empirical research about quality cost has allowed a strong relationship between customer satisfaction and the achievement of organizational goals, which ensures permanence in the markets and the operation of reports supplied by accounting departments. Marin (2009) kept his investigation in the state of the art TQM and financial results where he found that there was difficulty and lack of clarity for the analysis of studies reporting a positive relationship between both variables and in which an intermediate point is determined in the influence of factors like productivity and customer satisfaction. In the same way, Soltani, Lai, Javadeenc y Gholipour (2008) focused their study on showing evidence of TQM failure due to a lack of commitment by senior management which has fallen dramatically, according to this analysis which showed cases of leaders who lose interest in their groups, thus increasing employees frustration, through data they exposed the barriers to quality and productivity improvement for a culture success.

Hernández and González (2007) based their research on the design of a Continuous Improvement Strategic Model for the manufacturing SMEs, based on ISO 9001:2000 standards and it is based on the five core processes: organization, strategic process, training, business management skills and customer satisfaction. The objective is to facilitate continuous improvement by promoting cultural change in the organizations, and integrate human resources through competencies and indi- 
cators to analyze optimal quality costs as a measure of QMS. Moreover, Verde and Cárdenas (2008) mentioned that in order to meet customer and regulatory requirements, one of the expected benefits of QMS are those related to financial and economic costs, however, to get these benefits it is required that the senior management has defined the Quality Policy guidelines and through its display and interpretation to achieve QMS successful economic and financial performance by using costs mapping.

Gutiérrez, Tamayo and Barrales (2010) provided an approach that enables organizations to choose between different methodologies for QMS according to the degree of complexity and development, the results were: ISO standards are strategies for competing in international markets and if the company requires choosing more ambitious developed and complex quality strategies, EFQM model and Six Sigma methodology can be selected. For this, researchers used a variance analysis and t-students tests, with a sample of 234 organizations in Europe. On their part, Nava y Rivas (2008) determined in their study about QMS models in Mexico, that the correlation of ISO 9001:2000 and Quality Award had a significance level of 84.3\% and the benefits of ISO 9001:2000 correlated with the increase of sales in 88\%, and satisfaction costumer was $82 \%$. In turn, they exposed that when the motivation is passive, namely, the implementation is decided by the leaders without involving the staff, performance does not substantially improve in the organization.

\section{Innovation as a culture of excellence in the quality management system}

The globalized world exerts a constant pressure, today's inventions are overtaken by tomorrow's, achievements are copied within a few hours and this is a demand to renew continuous improvement programs that are faster and more flexible, it is not a question of when the customer wants it, but to do it before he changes his opinion. Therefore, it is necessary to establish strategies that emphasize the productive sector and contribute to regional development, that is why, in manufacturing SME's, innovation is diffuse and difficult to identify, considering that there is not the necessary evidence of it.

Torkkeli, Kock, Pekka and Salmi (2009) focused their work on the parameters that determine the types of innovation management, based on the generation of ideas and creativity and open innovation model derived from the motivation and exchange of knowledge between different factors. Moreover, Hoang, Igel and Laosirihongthong (2010) said that highly innovative companies showed a higher rate of implementation of TQM to difference businesses with poor performance innova- 
tion, suggesting that support of TQM generates results for innovation. On the other hand, Santos and Álvarez (2008) conducted their research on the effects of QMS and innovation on products and services and the relations with the processes, they observed that the relationship of this measure gives a positive culture, so QMS not only allows the company the development of incremental innovations, but also the development of new skills necessary to obtain radical innovations. While Ayala, Fernández and González (2004) mentioned that QMS requires guiding manufacturing SMEs about innovation processes, which is important to evaluate the degree of relationship between technological capabilities and QMS.

\section{Results}

The methodology was conducted across the review and interpretation of empirical and theoretical researches, which were analyzed and synthesized. The frequency of the variables specified in table 2 was focused on a simple analytical method to show the repeatability of the variables obtained in the review of literature from 39 authors about the involvement of human factors in QMS. Also, the study's variables were grouped by each author according to recurrence and were counted. Afterwards, subsequently the total amount for each of the percentages was added in an order from highest to lowest, the variables with highest percentages were identified keys for a conceptual model design. Validation of it was through this process repeatability.

The results of analyzed papers were: $28 \%$ of the authors mentioned that the main objective of an organization is to satisfy their customers, with respect to this approach, only two authors were identified, whose contribution was the value proposition to ensure satisfied customer. On the other hand, 25\% of the authors mentioned that the organization should improve worker satisfaction. However, few studies analyzed the attitudes and aptitudes to guarantee for effectiveness of QMS. In the same way, $12 \%$ correspond to EI variables, and $7 \%$ to ethical values, these variables have been scarcely treated by authors who consider them quality strategies in developing the human factor. Moreover, $12 \%$ of the authors mentioned that QMS must be managed through strategic planning and in turn, to improve the processes and getting the levels of reliability and accomplishment required, as well as integrate quality cost with tangible and intangible indicators than can ensure the continuous improvement cycle. Finally, $25 \%$ of the authors said that they must innovate in order to get a competitive advantage, involving creativity and ideas generated through the human factor (see table 2). 


\section{Table 2}

\section{Contributions by differents authors}

\begin{tabular}{|c|c|}
\hline Variables & Autores \\
\hline Quality culture & $\begin{array}{l}\text { Camisón and Pérez (2010), Belmares and Domínguez (2006), Elçi et al. (2007), } \\
\text { Tang et al. (2010), Calderón et al. (2006), Steward and Waddell (2008), Castro } \\
\text { et al. (2009), Hernández and González (2007), González and Michelena (2000), } \\
\text { Delgado et al. (2005), Kull and Narasimhan (2010), Rahman (2008), Soltani et } \\
\text { al. (2008). }\end{array}$ \\
\hline $\begin{array}{l}\text { Leadership, } \\
\text { organizational } \\
\text { commitment }\end{array}$ & $\begin{array}{l}\text { Camisón and Pérez (2010), Sunindijo et al. (2007), Maguad and Kroneb (2009), } \\
\text { Rahman (2008). }\end{array}$ \\
\hline $\begin{array}{l}\text { Knowledge, training, } \\
\text { education, talent }\end{array}$ & $\begin{array}{l}\text { Shackelford and Sun (2009), Calderón et al. (2006), Maguad and Kroneb (2009), } \\
\text { Tarí et al. (2005), Ismail et al. (2009). }\end{array}$ \\
\hline $\begin{array}{l}\text { Emotional } \\
\text { intelligence, aptitudes } \\
\text { and attitudes }\end{array}$ & $\begin{array}{l}\text { Belmares and Domínguez (2006), Shackelford and Sun (2009), Sunindijo et al. } \\
\text { (2007), González and Michelena (2000), Rahman (2008). }\end{array}$ \\
\hline $\begin{array}{l}\text { Principles and ethical } \\
\text { values }\end{array}$ & Tang et al. (2010), Maguad and Kroneb (2009), Kull and Narasimhan (2010). \\
\hline Job satisfaction & $\begin{array}{l}\text { Gutiérrez and Rubio (2009), Elçi et al. (2007), Sacklani (2010), Schenkel (2004), } \\
\text { Fotopoulos et al. (2010), Zeng et al. (2007), Parra et al. (2009), Wilford (2007), } \\
\text { Freitas (2009), Soltani et al. (2008), Torkkeli et al. (2009). }\end{array}$ \\
\hline $\begin{array}{l}\text { Strategic planning } \\
\text { (mission, vision and } \\
\text { objectives) }\end{array}$ & $\begin{array}{l}\text { Belmares and Domínguez (2006), Heras et al. (2009), Marín (2009), Hernández } \\
\text { and González (2007), Nava and Rivas (2008). }\end{array}$ \\
\hline $\begin{array}{l}\text { Management } \\
\text { processes }\end{array}$ & $\begin{array}{l}\text { Belmares and Domínguez (2006), Hoang et al. (2010), Fotopoulos et al. (2010), } \\
\text { Parra et al. (2009), Hernández and González (2007) Santos and Álvarez (2008). }\end{array}$ \\
\hline Quality cost & $\begin{array}{l}\text { Heras et al. (2009), Freitas (2009), López and Gracia (2008), Verde and Cárdenas } \\
\text { (2008), Nava and Rivas (2008). }\end{array}$ \\
\hline $\begin{array}{l}\text { Continuous } \\
\text { improvement }\end{array}$ & $\begin{array}{l}\text { Maguad and Kroneb (2009), Danvila and Sastre (2007), Hernández and González } \\
\text { (2007), González and Michelena (2000), Gotzamani (2010), Hurtado et al. } \\
\text { (2009), Soltani et al. (2008). }\end{array}$ \\
\hline $\begin{array}{l}\text { Innovation, } \\
\text { competitiveness } \\
\text { productivity, } \\
\text { creativity }\end{array}$ & $\begin{array}{l}\text { Camisón and Pérez (2010), Shackelford and Sun (2009), Marín (2009), Torkelli } \\
\text { et al. (2009), Hoang et al. (2010), Santos and Álvarez (2008), González and } \\
\text { Michelena (2000) Ayala et al. (2004), Rositas (2009), Soltani et al. (2008). }\end{array}$ \\
\hline Value propositions & Perdomo and González (2004), Ismail et al. (2009). \\
\hline $\begin{array}{l}\text { Customer and } \\
\text { stakeholder } \\
\text { satisfactions }\end{array}$ & $\begin{array}{l}\text { Belmares and Domínguez (2006), Palomo (2005), Perdomo and González (2004), } \\
\text { Gutiérrez and Rubio (2009), Elçi et al. (2007), Maguad and Kroneb (2009), } \\
\text { Fotopoulos et al. (2010), Marín (2009), Torkelli et al. (2009), Gotzamani (2010), } \\
\text { Ismail et al. (2009). }\end{array}$ \\
\hline
\end{tabular}

Based on the results which obtained the higher percentages the first conceptual relations were established, so-called major variables such as: worker satisfaction, 
quality culture, customer satisfaction, innovation, and finally QMS. This model aims to develop a new quality culture through employee involvement considering socio-emotional, intellectual and ethical values factors to create innovative value propositions to customers and stakeholders because these variables have been scarcely treated by different authors to improve QMS in the SMEs manufacturing sector in Mexico. That is why this model considered knowledge management as a support of the requirements of QMS which can ensure a competitive aptitude at all organization levels and together with this, incorporate disciplines such as EI, with integrate interpersonal and interpersonal skills, and ethical values, these key attitudes and aptitudes could achieve human quality in the organization and finally, the empowerment of its collaborators through the vision, mission and objectives of strategic leadership. In addition, it is desirable to integrate business strategies and QMS in accordance with the percentages obtained by variables which were considered by some authors as critical variables: strategic planning, process management, quality costs and continuous improvement. The union of these factors could ensure a QMS with human quality which can effectively address the company needs.

Figure 2

Model of human factor involvement in quality management systems

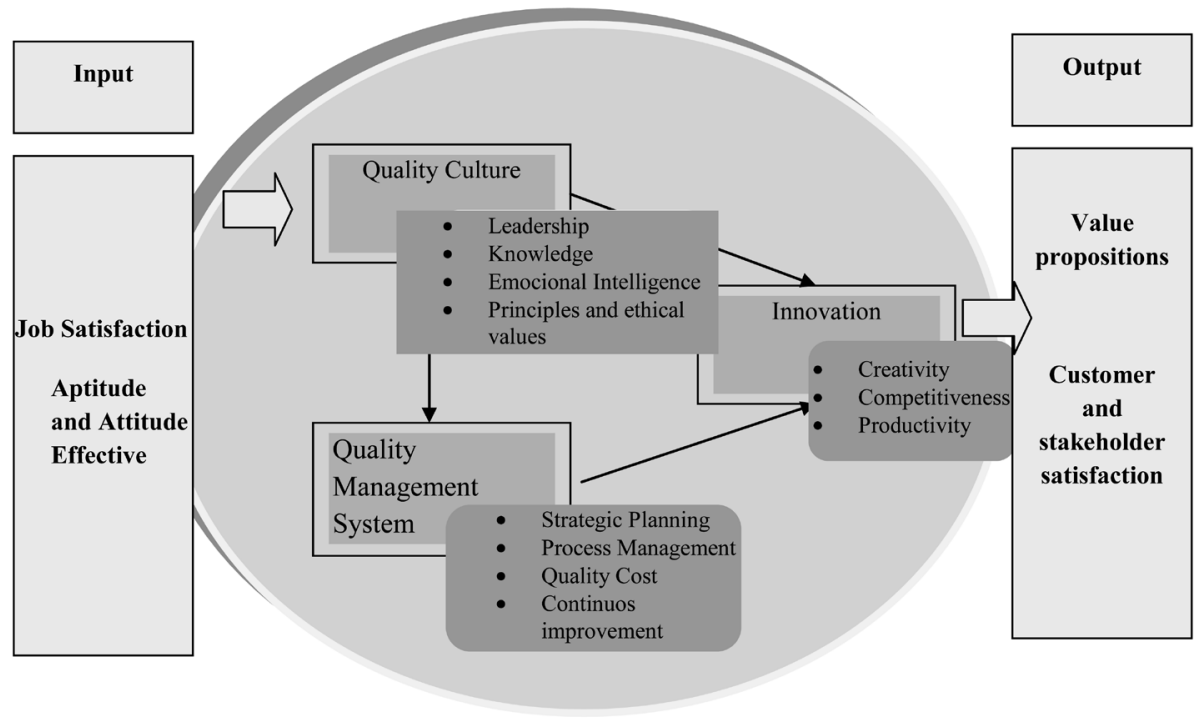




\section{Discussion}

According to literature on the subject it is confirmed that a wide variety of results involving the human factor exists in QMS in manufacturing SMEs, but they have been little treated with socio-emotional, intellectual factors and ethical values. $\mathrm{Ne}$ vertheless, several authors agreed that quality culture, job satisfaction, and innovation are the most important variables to customer satisfaction and the reason for QMS. However, few studies showed that aptitudes and attitudes on factors such as IE, knowledge and ethics values to enable Manufacturing SMEs provide strategies such as innovative value propositions to get a global competitive advantage in the context of QMS Manufacturing SMEs.

This conceptual model attempts to integrate the needs of QMS unlike other models such as: EFQM, ISO 9001, quality awards among others, to measure the effectiveness of human factors in terms of aptitude and attitude to variables such as emotional intelligence, knowledge management and ethical values in manufacturing SMEs in Mexico. In turn, this model considers the regulatory requirements that other QMS models demand, such as strategic planning, process management, quality costs, continuous improvement and innovation as key strategies. And just like other QMS models, the main objective is customer and stakeholder's satisfaction. On the other hand, this study could not resolve the items that integrate each variable of EI, knowledge management and ethics values in the QMS in Manufacturing SMEs in Mexico.

\section{Conclusions}

The review of the literature showed the integration of QMS and quality culture with human approach is a strategy of high impact for value propositions to customers and stakeholders, and through creativity and innovation, manufacturing SMEs can achieve a high degree of competitiveness and as mentioned above, it is necessary to integrate socio-emotional and intellectual factors, ethic values through the design of a quality and innovation model, to consider the value proposition to customers in all levels of the organization, This model of Human Factor integration in QMS will make an efficient human factor through their aptitudes and attitudes to improve QMS in manufacturing SMEs in Mexico.

Although, previous research has designed models that analyzed the relation of quality and the human factor and amply studied and considered direct and indirect 
variables, the highest percentage of this research is focused on isolated models. In this paper, it was concluded that there is a necessity of research in relation to integrate socio-emotional, intellectual, ethical values that benefit QMS. As a consequence, the development of a future research is focused on getting empirical results of the variables previously mentioned in this concept model, besides combining and integrating tangible and intangible indicators related to quality costs in different process levels of manufacturing SMEs in Mexico.

Finally, and based on observations made, there is not a method that can solve all the possible variations that exist in QMS of manufacturing SMEs in Mexico in relation to the human factor. The implications related to QMS derived from the review of literature are very different, and have been recognized and established. There are many factors that affect the relationship between the QMS. However, in the opinion of the authors of this contribution, the issues investigated in this paper made possible to design a new approach to the integration of human factors in the QMS of the manufacturing SMEs in Mexico.

\section{References}

Ayala, J. C., R. Fernández and M. L. González (2004). Capacidades tecnológicas y certificaciones de calidad. Aplicación empírica a las Pymes familiares de La Rioja. Cuadernos de Gestión 4 (1): 69-82.

Belmares, J. and C. H. Domínguez (2006). Customers and quality systems for your business Small Business Creativity. Administrate hoy: 56-57.

Braidot, N., H. Formento and I. Nicolini (2003). Desarrollo de una metodología de diagnóstico para empresas PyMes de Manufactura industriales y de servicio. Revista LITTEC s/p: 1-59.

Calderón, G., C. M. Álvarez and J. C. Naranjo (2006). Gestión humana en las organizaciones un fenómeno complejo: Evolución, retos, tendencias y perspectivas de investigación. Cuaderno de Administración Bogotá 19 (32): 225-254.

Camisón, C. and J. Pérez (2010). The future of the quality / excellence function: A view from the Spanish firm. Total Quality Management Business Excellence 21 (6): 649-672. 
Castro, J., M. González, G. Guenaga and J. J. Mijangos (2009). El factor liderazgo en el Modelo EFQM de Excelencia: análisis empírico en el País Vasco. Estudios de Economía Aplicada 27 (2): 1-34.

Castro, M. (2007). Ventajas del ISO-9001 para las MiPyMes Manufacturas. Disponible en: http://www.eluniversal.com.mx/articulos/43351.html.

Danvila, I. and M. A. Sastre (2007). El papel de la formación de personal en el proceso de implementación de un sistema de calidad total. Contaduría y Administración, mayo-agosto (222): 9-20.

Delgado, D. J., J. Liu and E. Aspinwall (2005). A comparative study of TQM critical success factors in manufacturing and construction UK industries. Proceedings of the 4th International Conference on Quality and Reliability ICQR. L. Cui, A. H. C. Tsang y M. Xie eds., Beijing Institute Of Technology: 135-145.

Freitas, D. S. (2009). La investigación empírica en contabilidad de gestión, la estrategia para el estudio de los costes de calidad en las organizaciones. Revista Venezolana de Análisis de Coyuntura 15 (2): 165-181.

Economic Commission for Latin America (2010). Growth prospects for Latin American Data Of CEPAL Consulta Mitofsky. Disponible en: www.consulta.com.mx .

Elçi, M., H. Kitapçi and A. Ertürk (2007). Effects of Quality Culture and Corporate Ethical Values and Corporate attitudes and Job Performance in Turkey: An Integrative Aproach. Total Quality Management \& Business Excellence 18 (3): 285-302.

Foro Económico Mundial The global competitiveness Report (2011-2012). Disponible en: http://www3.weforum.org/docs/WEF_GCR_Report_2011-12.pdf

Fotopoulos, Ch., E. Psomas and F. Vouzas (2010) Investigating total quality management practice's inter-relationships in ISO 9001:2000 certified organizations. Total Quality Management \& Business Excellence 21 (5): 503-515.

González, A. and E. Michelena (2000). La cultura de la organización en la gestión total de la calidad. Revista Ensaios e Ciências 4(3): 99-114 
Gutiérrez, S and M. Rubio (2009). El factor humano en los sistemas de gestión de calidad del servicio: un cambio de cultura en las empresas turísticas. Cuadernos de Turismo (23): 129-147.

Gutiérrez, L. J., I. Tamayo and V. Barrales (2010). Quality management initiatives in Europe: An empirical analysis according to their structural elements. Total Quality Management \& Business Excellence 21 (6): 577-601.

Gotzamani, K. (2010). Results of an empirical investigation on the anticipated improvement areas of the ISO 9001:2000 standard. Total Quality Management \& Business Excellence 21(6): 687-704.

Heras, I., F. Marimon and M. Casadesus (2009). Impacto competitivo de las herramientas de gestión de la calidad. Cuadernos de Economía y Dirección de la Empresa, diciembre (41): 7-35.

Hernández, M. and A. González (2007). Modelo Estratégico de Mejora Continua para la Pequeña y Mediana Empresa. Revista Industrial 18 (3): 30-38.

Hurtado, R., W. Rodríguez, H. Fuentes and C. Galleguillos (2009). Impacto en los beneficios de la implementación de las normas de calidad ISO 9001 en las empresas. Revista de la Facultad de Ingeniería (23):17 -26.

Hoang, D.T., B. Igel and T. Laosirihongthong (2010). Total quality management (TQM) strategy and organizational characteristics: Evidence from a recent WTO member Total Quality Management Business Excellence1 9(21): 931951.

Ismail, A., M. B. Madi Bin and S. K. Francis (2009). Exploring the relationships among service quality features, perceived value and customer satisfaction. Journal of Industrial Engineering and Mangament 2 (1): 230-250.

Kokt, D. (2009). A model for establishing a quality culture in a major private security company. Total Quality Management \& Business Excellence 20 (8): 787-798.

Kull, T. and R. Narasimhan (2010). Quality Management and Cooperative Values: Investigation of Multilevel Influences on Workgroup. Decision Sciences 41 (1): 81-113. 
Kuo, T-H. and Y-L. Kuo (2010). The effect of corporate culture and total quality management on construction project performance in Taiwan. Total Quality Management \& Business Excellence 21 (6): 617-632.

Macias, S. (s/f). La importancia de las Pymes para el mercado mexicano. Disponible en: http://www.compite.org.mx/otros/

Maguad, B. A. and R. M. Krone (2009). Ethics and moral leadership: Quality linkages. Total Quality Management \& Business Excellence 20 (2): 209222.

Marín, L. M. (2009). Enfoques de estudio y modelos de investigación sobre calidad y resultados: una revisión crítica. Cuadernos de Gestión 9 (2): 89-110.

Nava, V. M. and L. A. Rivas (2008). Desempeño de las Organizaciones mexicanas certificadas en la Normas ISO 9001:2000. Estudios Gerenciales (108): 107-128.

Organization for Economic Cooperation and Development (2009). Promoting entrepreneurship and innovative in a global economy SMEs. Towards a more responsible and inclusive globalization. Disponible en: http://www.oecd-ilibrary.org/science-and-technology/fostering-innovation-for-green-growth_ 9789264119925-en.

Organismo Internacional de Estandarización. Sistema de gestión de la calidad. Fundamentos y Vocabularios ISO 9000:2005 (2005). Disponible en: http:// www.uco.es/sae/archivo/normativa/ISO_9000_2005.pdf

Palomo, M. A. (2005). Los procesos de gestión y la problemática de las Pymes Manufactureras. Revista Ingenieras 8 (28): 25-31.

Perdomo, J. and J. González (2004). Medición de la Gestión de la calidad total: una revisión de la literatura. Cuadernos de Administración Bogotá 17 (28): 91-109.

Parra, C. M., V. M. Villa and J. W. Restrepo (2009). Gestión de la calidad con el modelo EFQM en 10 PyMes de Manufactura metalmecánica de Medellin. Revista Escuela de Ingeniería de Antoquia Julio (11): 9-19. 
Quazi, H. A., W. H. Chang and T. M. Chan (2002). Impact of ISO 9000 certification on quality management practices: a comparative study. Total Quality Management \& Business Excellence 13(1): 53-67.

Rahman, S. (2008). Quality management in logistics services: A comparison of practices between manufacturing companies and logistics firms in Australia. Total Quality Management \& Business Excellence 19 (5): 535-550.

Romero, I. (2006). Las Pyme en la economía global. Hacia una estrategia de fomento empresarial. Problemas de Desarrollo. Revista Latinoamericana de Economía 146 (37): 31-50.

Rositas, M. J. (2009). Factores críticos de éxito en la gestión de calidad total en la industria manufacturera. Ciencia Universidad Autónoma de Nuevo León XII (2): 181-193.

Santos, L. and I. Álvarez (2008). Efectos de la calidad total en la innovación tecnológica y administrativa. Cuadernos de Economía y Dirección en la Empresa (37): 33-65.

Schenkel, A. (2004). Conceptualizing and Exploring the Organizational Effects of ISO 9001:2000 Insights from the Øresund Bridge Project. Total Quality Management \& Business Excellence 15 (8):1155-1168.

Shackelford, A. and P. Sun (2009). Knowledge Management strategy employed in SMEs: the case of a Building Materials Supplier. Journal of Knowledge Management Practice 10 (4).

Sila, I. and M. Ebrahimpour (2003). Examination and comparison of the critical factors of total quality management (TQM) across countries. International Journal of Production Research 41 (2): 235-268.

Soltani, E., P-Ch. Lai, S. R. S. Javadeen and T. H. Gholipour (2008). A review of the theory and practice of managing TQM: An integrative framework. Total Quality Management \& Business Excellence 19 (5): 461-479. 
Stewart, D. and D. Waddell (2008). Knowledge Management: The fundamental component for delivery of Quality. Total Quality Management \& Business Excellence 9 (19): 987-996.

Sunindijo, R. Y., B. H. Hadikusumo and S. Ogunlana (2007). Emotional Intelligence and Leadership Styles in Construction: Project Management. Journal of Management in Engineering 23 (4): 166-170.

Tang, S. L., R. Aoieong and C. Tsui (2010). Quality Culture: Auditing for Engineering Consultants. Journal of Management in Engineering 25 (4): 2004-2013.

Tarí, J.J., F. Llopis, V. Sabater and M. Úbeda (2004-2005). Los recursos humanos en las empresas certificadas: un estudio descriptivo. Economía y Empresa 22 (52-53): 87-104.

Torkkeli, M., C. Kock and P. Salmi (2009). The open Innovation paradigm: A contingency perspective. Journal of Industrial Enginneering 2(1): 176-207.

Verde, A. H. and O. Cárdenas (2008). Despliegue de la función de la política de calidad. Revista Internacional La Nueva Gestión Organizacional 3 (6): 96-120.

Wilford, S. (2007). The Limits of Award Incentives: The (Non-) Relationship between Awards for Quality and Organizational Performance. Total Quality Management \& Business Excellence 18(3): 333-349.

Zeng, S. X., P. Tian and C. Tam (2007). Overcoming barriers to sustainable implementation of the ISO 9001 system. Managerial Auditing Journal 22 (3): 244-254. 
